\title{
Synthesis, characterization, crystal structure and DNA-binding study of four cadmium(II) pyridine-carboxamide complexes
}

\author{
BIPLAB MONDAL ${ }^{\mathrm{a}}$, BUDDHADEB SEN ${ }^{\mathrm{a}}$, SANDIPAN SARKAR $^{\mathrm{a}}$, ENNIO ZANGRANDO $^{\mathrm{b}}$ \\ and PABITRA CHATTOPADHYAY ${ }^{\mathrm{a}, *}$ \\ ${ }^{a}$ Department of Chemistry, Burdwan University, Golapbag, Burdwan, West Bengal 713 104, India \\ ${ }^{b}$ Department of Chemical and Pharmaceutical Sciences, Via Licio Giorgieri 1, 34127 Trieste, Italy \\ Email: pabitracc@yahoo.com
}

MS received 9 July 2016; revised 4 October 2016; accepted 21 November 2016

\begin{abstract}
Treatment of perchlorate or nitrate salt of cadmium(II) with carboxamide derivatives $(\underline{\mathbf{L}})$ generated four novel mononuclear metal complexes, represented as $\left[\mathrm{Cd}(\underline{\mathbf{L}})_{4}\right]\left(\mathrm{ClO}_{4}\right)_{2}(\mathbf{1 a}$ and $\mathbf{1 b})$ and $\left[\mathrm{Cd}(\underline{\mathbf{L}})_{2}\left(\mathrm{ONO}_{2}\right)_{2}\right]$ (2a and $\mathbf{2 b}$ ) in appreciable yields $\left(\underline{\mathbf{L}}=\mathbf{L}^{\mathbf{1}}=\mathrm{N}\right.$-(furan-2-ylmethyl)-2-pyridine carboxamide and $\underline{\mathbf{L}}=\mathbf{L}^{\mathbf{2}}=$ $\mathrm{N}$-(thiophen-2-ylmethyl)-2-pyridine carboxamide). The complexes have been characterized by FT-IR, UVVisible, elemental analysis and single crystal X-ray crystallographic analysis which revealed eight coordinated cadmium ions, but in different coordination environments, depending on the counter anion used. In addition, electronic absorption, fluorescence spectroscopy and viscosity measurements revealed a significant interaction of the four complexes with CT-DNA via intercalative/groove binding mode. The intrinsic binding constant $K_{\mathrm{b}}$ obtained varies from $0.4 \times 10^{4}$ to $1.11 \times 10^{5} \mathrm{M}^{-1}$. The results suggest that neutral complexes $\mathbf{2 a}$ and $\mathbf{2 b}$ bind to DNA in an intercalative mode. On the other hand, cationic complexes 1a and $\mathbf{1 b}$ bind with DNA via weak electrostatic/covalent interaction.
\end{abstract}

Keywords. Cadmium(II) complex; carboxamide ligand; crystal structures; DNA binding study.

\section{Introduction}

The coordination chemistry of carboxamide derivatives, especially towards transition metal ions, has attracted a considerable interest and this attention arises from the fact that pyridine carboxamide complexes have been used in various fields such as in asymmetric catalysis, ${ }^{1,2}$ dendrimers, ${ }^{3}$ molecular receptor synthesis ${ }^{4}$ and also in the synthesis of compounds with possible antitumor properties. ${ }^{5-8}$ The carboxamide $[-\mathrm{C}(\mathrm{O}) \mathrm{NH}-]$ group of the primary structure of proteins represents an important ligand building unit in coordination chemistry, since its chelating nature imparts a unique balance of stability versus reactivity and has allowed for remarkable developments in a variety of catalytic transformations. Cadmium is a highly toxic metal and a potent carcinogen. In fact, even at very low concentrations cadmium can cause extensive damage to kidney, liver, lungs, prostates and hematopoietic systems of humans, and it has been recognized by the International Agency for Research on Cancer as a carcinogenic agent. ${ }^{9}$ Recent studies suggest that cadmium-induced carcinogenicity involves direct or indirect interaction of this metal with DNA due to the various binding sites

*For correspondence presented in the double helix, ${ }^{10,11}$ although the exact molecular mechanism of cadmium-induced carcinogenicity remains mostly ambiguous. Antibacterial activities and binding ability of cadmium complexes with DNA have received a considerable interest. ${ }^{12-14}$ For instance, some $\mathrm{Cd}$ (II) complexes exhibit significant antitumor activity on murine melanoma B16 cells and human cervical cancer HeLa cells, ${ }^{15}$ showing an activity similar to cis-platin with $\mathrm{IC}_{50}$ less than $10.0 \mu \mathrm{M}$ for some cell lines such as MDA-361, MDA-453, HeLa, etc. ${ }^{14}$ As a result, investigations of interaction of cadmium complexes with DNA have been imperative in order to elucidate the mode and affinity of binding at cellular level. ${ }^{16}$

Herein, we report an account of the synthesis, structural characterization and DNA binding study of cadmium(II) complexes of two carboxamide derivatives $(\underline{\mathbf{L}})$ formulated as $\left[\mathrm{Cd}(\underline{\mathbf{L}})_{4}\right]\left(\mathrm{ClO}_{4}\right)_{2}(\underline{\mathbf{1}}),\left[\mathrm{Cd}(\underline{\mathbf{L}})_{2}\left(\mathrm{ONO}_{2}\right)_{2}\right]$ (2), where $\underline{\mathbf{L}}=\mathbf{L}^{1}=\mathrm{N}$-(furan-2-ylmethyl)-2-pyridinecarboxamide or $\underline{\mathbf{L}}=\mathbf{L}^{2}=\mathrm{N}$-(thiophen-2-ylmethyl)2-pyridinecarboxamide. The binding constants $\mathrm{K}_{\mathrm{b}}$ of these complexes with DNA have been obtained from UV-Vis spectra and the quenching constants $\mathrm{K}_{\mathrm{sv}}$ were determined from fluorescence displacement experiments using ethidium bromide (EB) as spectral probe. The binding affinity of these complexes with 
calf-thymus-DNA has also been studied by using viscosity measurements.

\section{Experimental}

\subsection{Materials and Physical measurements}

The chemicals and reagents used for the synthesis were obtained from commercial sources. Solvents were distilled from an appropriate drying agent. Calf thymus-DNA (Bangalore Genie, India) and ethidium bromide (Sigma) were used as received. All other chemicals and solvents were of analytical grade. The elemental $(\mathrm{C}, \mathrm{H}, \mathrm{N})$ analyses were performed on a Perkin Elmer model 2400 elemental analyzer. IR spectra and ${ }^{1} \mathrm{H}$ NMR spectra of complexes were recorded on a Perkin Elmer FTIR model RX1 spectrometer (KBr disc, 4000-400 $\mathrm{cm}^{-1}$ ) and on a Bruker Avance DPX $500 \mathrm{MHz}$ spectrometer using DMSO- $\mathrm{d}_{6}$ as solvent, respectively. The solution electrical conductivity was measured using Systronics 304 digital conductivity meter with a solution concentration of $c a .10^{-3}$ mol $\mathrm{dm}^{-3}$. The electronic absorption spectra were recorded on a JASCO UV-Vis/NIR spectrophotometer model V-570. The fluorescence spectra of the complexes bound to DNA were recorded with an excitation wavelength of $522 \mathrm{~nm}$ by using the Hitachi-4500 fluorimeter.

\subsection{Synthesis of ligands $\boldsymbol{L}^{1}$ and $\boldsymbol{L}^{2}$}

The organic ligands N-(furan-2-ylmethyl)-2-pyridinecarboxamide ( $\left.\mathbf{L}^{\mathbf{1}}\right)$ and N-(thiophen-2-ylmethyl)-2-pyridine-carboxamide $\left(\mathbf{L}^{2}\right)$ have been prepared as previously reported and duly characterised by single crystal X-ray crystallography. ${ }^{17}$

\subsection{Synthesis of cadmium(II) complexes}

The complexes were synthesized following a procedure as described below. The organic compound $(4.0 \mathrm{mmol}, 816$ $\mathrm{mg}$ of $\mathbf{L}^{1}$ or $872 \mathrm{mg}$ of $\mathbf{L}^{2}$ ) was dissolved in dry ethanol by stirring the mixture for $15 \mathrm{~min}$. To this solution, an ethanolic solution of cadmium(II) perchlorate hexahydrate $\left(\mathrm{Cd}\left(\mathrm{ClO}_{4}\right)_{2} .6 \mathrm{H}_{2} \mathrm{O}, 419 \mathrm{mg}, 1.0 \mathrm{mmol}\right)$ (for $\left.\underline{\mathbf{1}}\right)$ or cadmium(II) nitrate tetrahydrate $\left(\mathrm{Cd}\left(\mathrm{NO}_{3}\right)_{2} .4 \mathrm{H}_{2} \mathrm{O}, 309 \mathrm{mg}, 1.0 \mathrm{mmol}\right)$ (for 2 ) was added dropwise and the mixture was stirred 30 min and then refluxed for $5 \mathrm{~h}$ (Scheme 1). The resulting mixture was filtered off and the clear filtrate was collected. The filtrate was kept aside at room temperature and the volume of the solution was reduced by slow evaporation. The product was collected by washing with cold ethanol and water and dried in vacuo. Pure crystalline products, which were used for elemental analysis and for characterization using physico-chemical and spectroscopic tools, were obtained from ethanol. Single crystals of $\mathbf{1 a}$ and $\mathbf{2 b}$ suitable for X-ray diffraction study were obtained by slow evaporation of the ethanolic solution.

2.3.1 Complex 1a: $\left[\mathrm{Cd}\left(\mathrm{L}^{1}\right)_{4}\right]\left(\mathrm{ClO}_{4}\right)_{2}$ : Yield: $65-70 \%$ $(0.772 \mathrm{~g}) ; \mathrm{C}_{44} \mathrm{H}_{40} \mathrm{CdCl}_{2} \mathrm{~N}_{8} \mathrm{O}_{16}$ : Anal. Found: $\mathrm{C}, 47.11 ; \mathrm{H}$, 3.55; N, 9.92; Cd, 9.97\% Calc.: C, 47.18; H, 3.60; N, 10.00; $\mathrm{Cd}, 10.04 \%$ IR $\left(\mathrm{cm}^{-1}\right): v_{\mathrm{C}=\mathrm{N}}, 1475, v_{\mathrm{ClO} 4}^{-} 1087,628, v_{\mathrm{C}=\mathrm{O}}$ $1643, v_{\mathrm{N}-\mathrm{H}} 3337$; Conductivity $\left(\Lambda_{\mathrm{o}}, \mathrm{ohm}^{-1} \mathrm{~cm}^{2} \mathrm{~mol}^{-1}\right)$ in MeOH: $214 ;{ }^{1} \mathrm{H}$ NMR ( $\delta$, ppm in Dmso-d $\left.{ }_{6}\right)$ : $9.01(\mathrm{t}, 1 \mathrm{H})$; $8.53(\mathrm{~d}, 1 \mathrm{H}) ; 7.92(\mathrm{~m}, 2 \mathrm{H}) ; 7.50(\mathrm{~m}, 1 \mathrm{H}) ; 7.43(\mathrm{~s}, 1 \mathrm{H}) ; 6.27$ $(\mathrm{t}, 1 \mathrm{H}), 6.16(-\mathrm{NH}), 4.38\left(\mathrm{~s}, 2 \mathrm{H}\right.$ of $\left.\mathrm{CH}_{2}\right)$.

2.3.2 Complex 1b: $\left[\mathrm{Cd}\left(\mathrm{L}^{2}\right)_{4}\right]\left(\mathrm{ClO}_{4}\right)_{2}$ : Yield: $65-70 \%$ $(0.807 \mathrm{~g}) ; \mathrm{C}_{44} \mathrm{H}_{40} \mathrm{CdCl}_{2} \mathrm{~N}_{8} \mathrm{O}_{12} \mathrm{~S}_{4}$ : Anal. Found: $\mathrm{C}, 40.91 ; \mathrm{H}$, 3.25; N, 8.58; Cd, $11.53 \%$ Calc.: C, 41.02; H, 3.13; N, 8.70; $\mathrm{Cd}, 11.64 \%$. IR $\left(\mathrm{cm}^{-1}\right): v_{\mathrm{C}=\mathrm{N}}, 1469, v_{\mathrm{ClO} 4}^{-} 1087,628, v_{\mathrm{C}=\mathrm{O}}$ $1634, v_{\mathrm{N}-\mathrm{H}} 3314$. Conductivity $\left(\Lambda_{\mathrm{o}}, \mathrm{ohm}^{-1} \mathrm{~cm}^{2} \mathrm{~mol}^{-1}\right)$ in MeOH: 204. ${ }^{1} \mathrm{H}$ NMR $\left(\delta\right.$, ppm in dmso-d $\left.\mathrm{d}_{6}\right): 9.24(\mathrm{t}, 1 \mathrm{H})$; $8.47(\mathrm{~d}, 1 \mathrm{H}) ; 7.95(\mathrm{~m}, 2 \mathrm{H}) ; 7.60(\mathrm{~m}, 1 \mathrm{H}) ; 7.31(\mathrm{~s}, 1 \mathrm{H}) ; 7.01$ $(\mathrm{t}, 1 \mathrm{H}), 6.20(-\mathrm{NH}), 4.40\left(\mathrm{~s}, 2 \mathrm{H}\right.$ of $\left.\mathrm{CH}_{2}\right)$.

2.3.3 Complex 2a: [Cd( $\left.\left.\mathrm{L}^{\mathbf{1}}\right)_{2}\left(\mathrm{ONO}_{2}\right)_{2}\right]$ : Yield: $70-74 \%$ $(0.467 \mathrm{~g}) ; \mathrm{C}_{22} \mathrm{H}_{20} \mathrm{CdN}_{6} \mathrm{O}_{10}$ : Anal. Found: $\mathrm{C}, 41.16 ; \mathrm{H}, 3.09$; N, 13.07; Cd, 17.46\% Calc.: C, 41.23; H, 3.15; N, 13.11; Cd, 17.54\%. IR $\left(\mathrm{cm}^{-1}\right)$ : $v_{\mathrm{NO} 3}^{-} 1381, v_{\mathrm{C}=\mathrm{O}} 1643, v_{\mathrm{N}-\mathrm{H}} 3336$. Conductivity $\left(\Lambda_{\mathrm{o}}, \mathrm{ohm}^{-1} \mathrm{~cm}^{2} \mathrm{~mol}^{-1}\right)$ in $\mathrm{MeOH}: 12.2 .{ }^{1} \mathrm{H} \mathrm{NMR}$ $\left(\delta\right.$, ppm in dmso-d $\left.{ }_{6}\right): 9.34(\mathrm{t}, 1 \mathrm{H}) ; 8.63(\mathrm{~d}, 1 \mathrm{H}) ; 7.92(\mathrm{~m}, 2 \mathrm{H})$; $7.57(\mathrm{~m}, 1 \mathrm{H}) ; 7.40(\mathrm{~s}, 1 \mathrm{H}) ; 6.31(\mathrm{t}, 1 \mathrm{H}), 6.58(-\mathrm{NH}), 4.71$ (s, $2 \mathrm{H}$ of $\left.\mathrm{CH}_{2}\right)$.

2.3.4 Complex 2b: $\left[\mathrm{Cd}\left(\mathrm{L}^{2}\right)_{2}\left(\mathrm{ONO}_{2}\right)_{2}\right]$ : Yield: $70-74 \%$ $(0.492 \mathrm{~g}) ; \mathrm{C}_{22} \mathrm{H}_{20} \mathrm{CdN}_{6} \mathrm{O}_{8} \mathrm{~S}_{2}$ : Anal. Found: $\mathrm{C}, 39.13 ; \mathrm{H}$, 2.91; N, 12.37; Cd, 16.64\% Calc.: C, 39.26; H, 3.00; N,

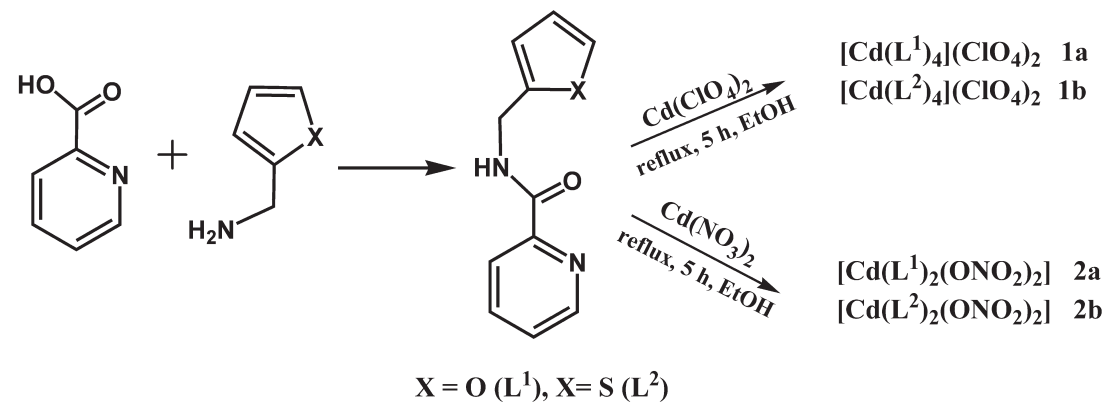

Scheme 1. Reaction scheme. 
12.49; Cd, 16.70\%; IR $\left(\mathrm{cm}^{-1}\right): v_{\mathrm{C}=\mathrm{N}}, 1473, v_{\mathrm{NO} 3}^{-} 1383, v_{\mathrm{C}=\mathrm{O}}$ 1633, $v_{\mathrm{N}-\mathrm{H}}$ 3312. Conductivity $\left(\Lambda_{\mathrm{o}}, \mathrm{ohm}^{-1} \mathrm{~cm}^{2} \mathrm{~mol}^{-1}\right)$ in MeOH: 13.3. ${ }^{1} \mathrm{H}$ NMR ( $\delta$, ppm in dmso-d 6 ): $9.40(\mathrm{t}, 1 \mathrm{H})$; $8.60(\mathrm{~d}, 1 \mathrm{H}) ; 8.01(\mathrm{~m}, 2 \mathrm{H}) ; 7.60(\mathrm{~m}, 1 \mathrm{H}) ; 7.35(\mathrm{~s}, 1 \mathrm{H}) ; 7.01$ $(\mathrm{t}, 1 \mathrm{H}), 6.90(-\mathrm{NH}), 4.64\left(\mathrm{~s}, 2 \mathrm{H}\right.$ of $\left.\mathrm{CH}_{2}\right)$.

\section{$2.4 X$-ray crystal structure analysis}

X-ray single crystal data of $\mathbf{1 a}$ and $\mathbf{2 b}$ were collected at room temperature $(296(2) \mathrm{K})$ using $\mathrm{Mo}_{\alpha} \mathrm{K}_{\alpha}$ radiation $(\lambda=0.71073$ $\AA$ ) on a SMART APEX II diffractometer equipped with CCD area detector. Data collection, data reduction, structure solution/refinement were carried out using the SMART APEX II package. ${ }^{18}$ The structures were solved by direct methods of SHELXS-97 and refined by full-matrix least squares refinement methods based on $F^{2}$ with SHELXL-97 program. ${ }^{19}$ All non-hydrogen atoms were refined anisotropically. In compound 1, one furanyl ring (O6/C30-33) was fitted by using an input fragment due to a slight disorder of the group. All calculations were performed using the WinGX package. ${ }^{20}$ Crystal data and details of the refinement are reported in Table 1, and a selection of bond lengths and angles are shown in Table 2.

\subsection{DNA binding experiments: Study with UV spectroscopy}

Tris- $\mathrm{HCl}$ buffer solution ( $\mathrm{pH}=7.2$ ) used in all the experiments involving CT-DNA was prepared using deionized and sonicated HPLC grade water (Merck). The CT-DNA used in the experiments was checked to be sufficiently free from protein by using the ratio of UV absorbance of DNA solution in tris- $\mathrm{HCl}$ at $260 \mathrm{~nm}$ and $280 \mathrm{~nm}\left(\mathrm{~A}_{260} / \mathrm{A}_{280}\right)$ that was around 1.9. ${ }^{21}$ The concentration of DNA was estimated by using the extinction coefficient $\left(6600 \mathrm{M}^{-1} \mathrm{~cm}^{-1}\right)$ at 261 $\mathrm{nm}^{22}$ and stock solution of DNA was always stored at $4^{\circ} \mathrm{C}$. The stock solution of each complex was prepared by dissolving it in $2 \mathrm{~mL}$ of DMSO and diluted with Tris-HCl buffer to get the required concentration for all the experiments. Absorption spectral titration experiment was performed by maintaining constant complex concentration and varying the CT-DNA concentration. To eliminate the absorbance by DNA itself, equal amount of CT-DNA was added to the reference solution.

2.5.1 EB competitive studies with fluorescence spectroscopy In the ethidium bromide (EB) fluorescence displacement experiment, $5.0 \mu \mathrm{L}$ of EB tris- $\mathrm{HCl}$ solution $(1.0 \mathrm{mM})$ was added to $1.0 \mathrm{~mL}$ of DNA solution (at saturated binding levels $)^{16}$ and stored in the dark for $2.0 \mathrm{~h}$. Then, the solution of the complex was titrated into the DNA/EB mixture and diluted with tris- $\mathrm{HCl}$ buffer to $5.0 \mathrm{~mL}$ to get the solution with the appropriate complex/CT-DNA mole ratio. Before measurements, the mixture was shaken up and incubated at room temperature for $30 \mathrm{~min}$. The fluorescence spectra of $\mathrm{EB}$ bound to DNA were obtained in the fluorimeter at $\lambda_{\mathrm{ex}}=522$ $\mathrm{nm}$.

2.5.2 Viscosity measurements: To adjudge the binding mode (groove/intercalative) of complex with DNA, viscosity measurements were performed by employing the Ostwald's viscometer. Titrations were carried out in the viscometer by

Table 1. Crystallographic data and details of refinement for complexes $\mathbf{1 a}$ and $\mathbf{2 b}$.

\begin{tabular}{|c|c|c|}
\hline & 1a & $2 b$ \\
\hline Empirical Formula & $\mathrm{C}_{44} \mathrm{H}_{40} \mathrm{CdCl}_{2} \mathrm{~N}_{8} \mathrm{O}_{16}$ & $\mathrm{C}_{22} \mathrm{H}_{20} \mathrm{CdN}_{6} \mathrm{O}_{8} \mathrm{~S}_{2}$ \\
\hline Formula Weight & 1120.14 & 672.97 \\
\hline Crystal System & monoclinic & monoclinic \\
\hline Space group & $P 21 / c$ & $P 2_{1}$ \\
\hline $\mathrm{a}(\AA)$ & $11.8592(3)$ & $8.5523(9)$ \\
\hline $\mathrm{b}(\AA)$ & $23.2387(6)$ & $15.6446(15)$ \\
\hline$c(\AA)$ & $18.9971(5)$ & $10.1662(10)$ \\
\hline$\beta\left(^{\circ}\right)$ & $105.953(1)$ & $104.098(4)$ \\
\hline Density, $\mathrm{g} \mathrm{cm}^{-3}$ & 1.478 & 1.694 \\
\hline Volume $\left(\AA^{3}\right)$ & $5033.8(2)$ & $1319.2(2)$ \\
\hline $\mathrm{Z}$ & 4 & 2 \\
\hline $\mathrm{F}(000)$ & 2280 & 676 \\
\hline$\theta$ range $\left(^{\circ}\right)$ & $1.78-24.10$ & $2.44-32.89$ \\
\hline Collected reflections & 67231 & 27578 \\
\hline Independent reflections & 7928 & 8219 \\
\hline Rint & 0.0460 & 0.0433 \\
\hline Goodness-of-fit & 1.025 & 1.085 \\
\hline$R 1[I>2.0 \sigma(I)]$ & 0.0595 & 0.0394 \\
\hline$w R 2[I>2.0 \sigma(I)]$ & 0.1617 & 0.1038 \\
\hline Flack parameter & - & $0.038(11)$ \\
\hline
\end{tabular}

${ }^{[\mathrm{a}]} R 1=\Sigma\|F o|-| F c\| / \Sigma|F o|, w R 2=\left[\Sigma \mathrm{w}\left(\mathrm{Fo}^{2}-\mathrm{Fc}^{2}\right)^{2} / \Sigma \mathrm{w}\left(\mathrm{Fo}^{2}\right)^{2}\right] 1 / 2$. 
Table 2. Selected coordination bond lengths $[\AA]$ and angles $\left[^{\circ}\right]$ for complexes $\mathbf{1 a}$ and $\mathbf{2 b}$.

Complex 1a

\begin{tabular}{|c|c|c|c|}
\hline \multicolumn{4}{|c|}{ Bond lengths $(\AA)$} \\
\hline $\mathrm{Cd}-\mathrm{N}(1)$ & $2.436(5)$ & $\mathrm{Cd}-\mathrm{O}(1)$ & $2.437(4)$ \\
\hline $\mathrm{Cd}-\mathrm{N}(3)$ & $2.414(5)$ & $\mathrm{Cd}-\mathrm{O}(3)$ & $2.459(4)$ \\
\hline $\mathrm{Cd}-\mathrm{N}(5)$ & $2.444(5)$ & $\mathrm{Cd}-\mathrm{O}(5)$ & $2.441(4)$ \\
\hline $\mathrm{Cd}-\mathrm{N}(7)$ & $2.397(5)$ & $\mathrm{Cd}-\mathrm{O}(7)$ & $2.417(4)$ \\
\hline \multicolumn{4}{|c|}{ Bond angles $\left(^{\circ}\right)$} \\
\hline $\mathrm{N}(1)-\mathrm{Cd}-\mathrm{O}(1)$ & $66.77(16)$ & $\mathrm{O}(3)-\mathrm{Cd}-\mathrm{O}(5)$ & $129.23(15)$ \\
\hline $\mathrm{N}(3)-\mathrm{Cd}-\mathrm{O}(3)$ & $66.90(17)$ & $\mathrm{O}(5)-\mathrm{Cd}-\mathrm{O}(7)$ & $129.65(16)$ \\
\hline $\mathrm{N}(5)-\mathrm{Cd}-\mathrm{O}(5)$ & $66.96(16)$ & $\mathrm{O}(1)-\mathrm{Cd}-\mathrm{O}(5)$ & $73.27(15)$ \\
\hline $\mathrm{N}(7)-\mathrm{Cd}-\mathrm{O}(7)$ & $67.53(15)$ & $\mathrm{O}(3)-\mathrm{Cd}-\mathrm{O}(7)$ & $74.51(15)$ \\
\hline $\mathrm{N}(1)-\mathrm{Cd}-\mathrm{N}(5)$ & $152.63(17)$ & $\mathrm{N}(1)-\mathrm{Cd}-\mathrm{N}(7)$ & $93.49(18)$ \\
\hline $\mathrm{N}(3)-\mathrm{Cd}-\mathrm{N}(7)$ & 151.08(18) & $\mathrm{N}(1)-\mathrm{Cd}-\mathrm{N}(3)$ & $92.87(19)$ \\
\hline $\mathrm{O}(1)-\mathrm{Cd}-\mathrm{O}(3)$ & 129.96(16) & $\mathrm{N}(3)-\mathrm{Cd}-\mathrm{N}(5)$ & $89.05(18)$ \\
\hline $\mathrm{O}(1)-\mathrm{Cd}-\mathrm{O}(7)$ & $129.95(14)$ & $\mathrm{N}(5)-\mathrm{Cd}-\mathrm{N}(7)$ & $97.94(18)$ \\
\hline \multicolumn{4}{|l|}{ Complex 2b } \\
\hline \multicolumn{4}{|c|}{ Bond lengths ( } \\
\hline $\mathrm{Cd}-\mathrm{N}(1)$ & $2.360(4)$ & $\mathrm{Cd}-\mathrm{O}(3)$ & $2.424(5)$ \\
\hline $\mathrm{Cd}-\mathrm{O}(1)$ & $2.354(4)$ & $\mathrm{Cd}-\mathrm{O}(4)$ & $2.530(6)$ \\
\hline $\mathrm{Cd}-\mathrm{N}(3)$ & $2.362(4)$ & $\mathrm{Cd}-\mathrm{O}(6)$ & $2.572(5)$ \\
\hline $\mathrm{Cd}-\mathrm{O}(2)$ & $2.354(4)$ & $\mathrm{Cd}-\mathrm{O}(7)$ & $2.426(4)$ \\
\hline \multicolumn{4}{|c|}{ Bond angles $\left(^{\circ}\right)$} \\
\hline $\mathrm{N}(1)-\mathrm{Cd}-\mathrm{O}(1)$ & $69.84(12)$ & $\mathrm{N}(3)-\mathrm{Cd}-\mathrm{O}(3)$ & $152.03(15)$ \\
\hline $\mathrm{N}(3)-\mathrm{Cd}-\mathrm{O}(2)$ & $70.08(13)$ & $\mathrm{N}(3)-\mathrm{Cd}-\mathrm{O}(4)$ & $150.50(15)$ \\
\hline $\mathrm{O}(3)-\mathrm{Cd}-\mathrm{O}(4)$ & 49.97(17) & $\mathrm{N}(3)-\mathrm{Cd}-\mathrm{O}(6)$ & $87.68(19)$ \\
\hline $\mathrm{O}(6)-\mathrm{Cd}-\mathrm{O}(7)$ & $50.64(15)$ & $\mathrm{N}(3)-\mathrm{Cd}-\mathrm{O}(7)$ & $78.86(14)$ \\
\hline $\mathrm{N}(1)-\mathrm{Cd}-\mathrm{O}(3)$ & $85.76(15)$ & $\mathrm{N}(1)-\mathrm{Cd}-\mathrm{N}(3)$ & $98.69(13)$ \\
\hline $\mathrm{N}(1)-\mathrm{Cd}-\mathrm{O}(4)$ & $103.86(17)$ & $\mathrm{O}(1)-\mathrm{Cd}-\mathrm{O}(2)$ & $145.01(14)$ \\
\hline $\mathrm{N}(1)-\mathrm{Cd}-\mathrm{O}(6)$ & $158.78(15)$ & $\mathrm{O}(2)-\mathrm{Cd}-\mathrm{N}(1)$ & $87.53(15)$ \\
\hline $\mathrm{N}(1)-\mathrm{Cd}-\mathrm{O}(7)$ & $150.42(14)$ & $\mathrm{O}(1)-\mathrm{Cd}-\mathrm{N}(3)$ & $86.85(13)$ \\
\hline
\end{tabular}

adding the complex $(0.5-3.5 \mu \mathrm{M})$ to the CT-DNA solution $(5.0 \mu \mathrm{M})$. The viscosity of the solutions were calculated from the observed flow time of CT-DNA-containing solution corrected from the flow time of buffer alone $\left(\mathrm{t}_{0}\right), \eta=\mathrm{t}-\mathrm{t}_{0}$. The obtained data were used to plot the $\left(\eta / \eta_{0}\right)^{1 / 3}$ versus the ratio of the concentration of complex to CT-DNA, where $\eta$ and $\eta_{0}$ are the viscosity of the CT-DNA solution in the presence of complex and CT-DNA solution only, respectively.

\section{Results and Discussion}

\subsection{Synthesis and characterization}

The perchlorate and nitrate salt of cadmium(II) were reacted with two carboxamide derivatives $\mathbf{L}^{1}$ and $\mathbf{L}^{\mathbf{2}}$ to form four new mononuclear cadmium complexes in ethanol medium at ambient temperature. The complexes, which revealed to be stable in air and soluble in methanol, DMF, DMSO, etc., were characterized by physico-chemical and spectroscopic tools.

\subsection{Structure of complexes}

3.2.1 Crystal structure of 1a: An Ortep view of complex 1a, crystallizing in monoclinic system, space group $P 2_{1} / \mathrm{c}$, is depicted in Figure 1, and selected bond lengths and angles are listed in Table 2.

The metal ion is coordinated by four chelating $\mathbf{L}^{1}$ ligands through the pyridine nitrogen and carbonyl oxygen giving a distorted square antiprismatic geometry with a $\mathrm{N}_{4} \mathrm{O}_{4}$ chromophore. The asymmetric ligands $\mathbf{L}^{\mathbf{1}}$ chelate the metal with $\mathrm{Cd}-\mathrm{N}$ and $\mathrm{Cd}-\mathrm{O}$ bond distances in the range 2.397(5)-2.444(5) and 2.417(4)-2.459(4) $\AA$, respectively. The chelating angle in all cases is very similar, between $66.77(16)-67.53(15)^{\circ}$. The arrangement of ligands around the metal is such that the trans chelating pyridine-carboxamide fragments are oriented head-head with $\mathrm{N}(1)-\mathrm{Cd}-\mathrm{N}(5)$ and $\mathrm{N}(3)-\mathrm{Cd}-\mathrm{N}(7)$ bond angles of $152.63(17)$ and $151.08(18)^{\circ}$, respectively. The present coordination metal-ligand bond distances are as expected for eight-coordinated Cd(II) complexes with four $N, O$-chelating ligands. ${ }^{23}$

The perchlorate ions are weakly bound to the complexes through $\mathrm{H}$-bonds involving $\mathrm{NH}$ groups and perchlorate anions (Table 3 and Figure S1, in Supplementary Information), and these interactions give rise to a $1 \mathrm{D}$ chain developed along axis $c$. In addition, a short ring interaction between thiophene S1 and pyridine N1 of a symmetry related complex (centroid-tocentroid distance $=3.707(4) \AA$; dihedral angle between planes $\left.=2.3(3)^{\circ}\right)$ is detected in the crystal packing.

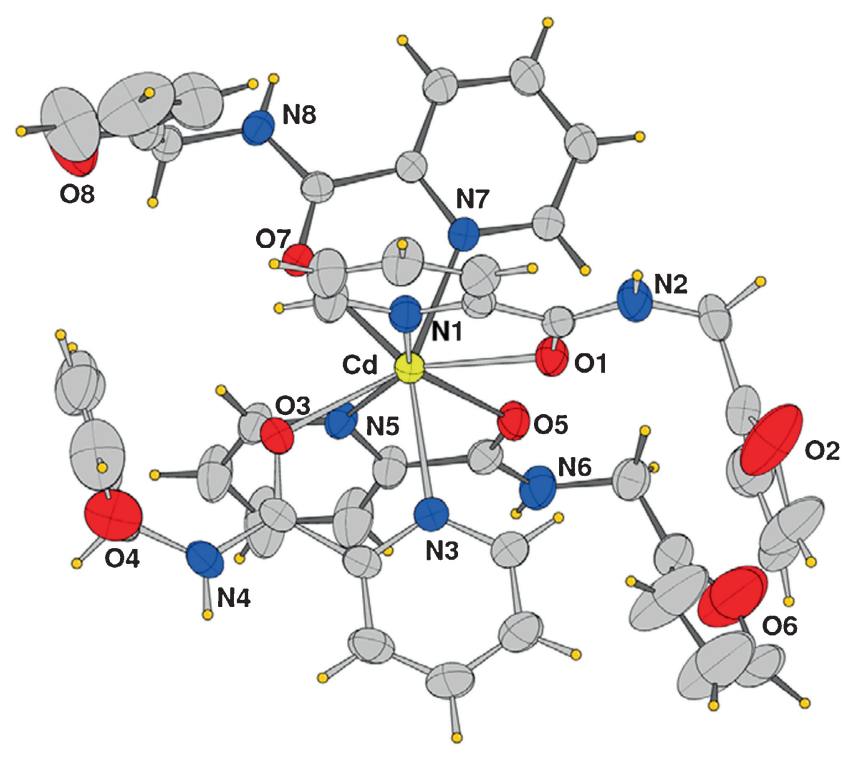

Figure 1. ORTEP view (ellipsoid probability at 30\%) of the cationic complex 1a, $\left[\mathrm{Cd}\left(\mathrm{L}^{1}\right)_{4}\right]^{2+}$ (carbon atoms are not labelled for the sake of clarity). 
Table 3. Hydrogen bond distances $(\AA)$ and angles $\left(^{\circ}\right)$ in complexes $\mathbf{1 a}$ and $\mathbf{2 b}$.

\begin{tabular}{lccccc}
\hline $\mathrm{D}-\mathrm{H} . . . \mathrm{A}$ & $\mathrm{d}(\mathrm{D}-\mathrm{H})$ & $\mathrm{d}(\mathrm{H} . . . \mathrm{A})$ & $\mathrm{d}(\mathrm{D} \ldots \mathrm{A})$ & $\angle$ (DHA) & A symmetry code \\
\hline $\mathbf{1 a}$ & & & & & \\
$\mathrm{N}(2)-\mathrm{H} . . . \mathrm{O}(10)$ & 0.86 & 2.17 & $2.985(12)$ & 158 & $1+\mathrm{x}, \mathrm{y}, \mathrm{z}$ \\
$\mathrm{N}(4)-\mathrm{H} \ldots \mathrm{O}(16)$ & 0.86 & 2.27 & $3.089(14)$ & 160 & $1-\mathrm{x}, 1 / 2+\mathrm{y}, 1 / 2-\mathrm{z}$ \\
$\mathrm{N}(8)-\mathrm{H} . . . \mathrm{O}(10)$ & 0.86 & 2.25 & $3.085(11)$ & 164 & $1+\mathrm{x}, 1 / 2-\mathrm{y},-1 / 2+\mathrm{z}$ \\
$\mathbf{2 b}$ & & & & & \\
$\mathrm{N}(2)-\mathrm{H} . . . \mathrm{O}(8)$ & 0.86 & 2.13 & $2.899(6)$ & 149 & $\mathrm{x}, \mathrm{y}, 1+\mathrm{z}$ \\
$\mathrm{N}(4)-\mathrm{H} . . . \mathrm{O}(7)$ & 0.86 & 2.07 & $2.864(7)$ & 153 & $-\mathrm{x},-1 / 2+\mathrm{y},-\mathrm{z}$ \\
\hline
\end{tabular}

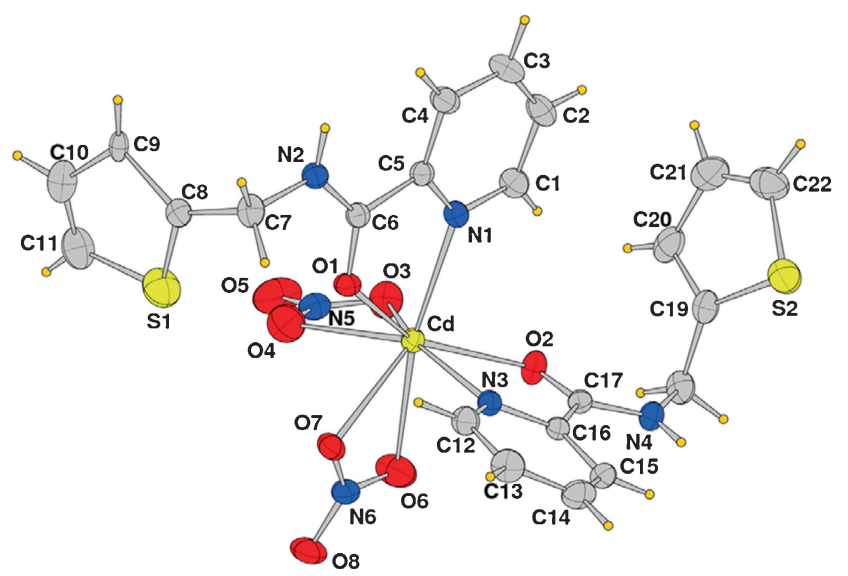

Figure 2. ORTEP view (ellipsoid probability at $40 \%$ ) of complex $\mathbf{2 b}$, $\left[\mathrm{Cd}\left(\mathrm{L}^{2}\right)_{2}\left(\mathrm{ONO}_{2}\right)_{2}\right]$.

3.2.2 Crystal structure of $\mathbf{2 b}$ : The X-ray diffraction study revealed that the complex crystallizes in monoclinic system, space group $P 2_{1}$. The metal is coordinated by two N,O chelating $\mathbf{L}^{2}$ and by two chelating nitrate anions leading to a neutral molecular species (see Figure 2). The $\mathrm{Cd}$ atom exhibits a distorted dodecahedron environment with $\mathrm{Cd}-\mathrm{O}\left(\mathbf{L}^{2}\right)$ and the $\mathrm{Cd}-\mathrm{N}$ bond distances are slightly shorter (mean $2.357 \AA$ ) than those measured in 1a, likely for the lower bulkiness of nitrates, which present an unsymmetrical coordination. In fact, in each nitrate one $\mathrm{Cd}-\mathrm{O}$ bond distance is shorter by about $0.11-0.13 \AA$ compared to the other (2.424(5) vs 2.530(6) and 2.426(4) vs 2.572(5) §). The chelating pyridine-carboxamide mean planes form a dihedral angle of $75.78(1)^{\circ}$, while the two nitrate mean planes define an angle of $64.60(1)^{\circ}$.

Cadmium(II) complexes with the same coordination environment have been previously reported, ${ }^{24,25}$ having coordination bond distance values in agreement with those reported herein. In the crystal lattice, the monomeric units form a 2D polymeric layered supramolecular stucture parallel to the crystallographic $b c$ plane through intermolecular hydrogen bonds between the carboxamide $\mathrm{N}-\mathrm{H}$ fragments and nitrate anions
(Figure 3). The hydrogen bonding parameters are reported in Table 3.

\subsection{Spectral characterization}

The IR spectrum of the ligand $\mathbf{L}^{1}$ shows absorption at 3344 and $1660 \mathrm{~cm}^{-1}$ assignable to the $v_{\mathrm{N}-\mathrm{H}}$ and $v_{\mathrm{C}=\mathrm{O}}$ stretching, respectively. In the spectra of both complexes $1 \mathbf{a}$ and $\mathbf{2 a}, v_{\mathrm{C}=\mathrm{O}}$ band moved towards lower frequency at $1643 \mathrm{~cm}^{-1}$, suggesting the coordination of the metal center via the carbonyl oxygen. Both complexes 1a and 2a show characteristic IR bands at 3347 and $3336 \mathrm{~cm}^{-1}$, which correspond to the characteristic peaks of $\nu_{\mathrm{N}-\mathrm{H}}$, in addition to a characteristic band at $1475 \mathrm{~cm}^{-1}$ assignable to the $v_{\mathrm{C}=\mathrm{N}}$ stretching frequency. The symmetric and asymmetric stretching vibrations of the perchlorate groups of complex 1a appear at 1087 and $628 \mathrm{~cm}^{-1}$, respectively. On the other hand, complex 2a displays a characteristic band at $1381 \mathrm{~cm}^{-1}$ assigned to $v_{\mathrm{NO} 3}^{-}$.

In the IR spectrum of the ligand $\mathbf{L}^{2}$, the absorption at 3317 and at $1654 \mathrm{~cm}^{-1}$ are assigned to the $v_{\mathrm{N}-\mathrm{H}}$ and to the $v_{\mathrm{C}=0}$, respectively. In the spectra of both complexes $\mathbf{1 b}$ and $\mathbf{2 b}$, the $v_{\mathrm{C}=\mathrm{O}}$ band is shifted to a lower frequency $\left(1634 \mathrm{~cm}^{-1}\right)$, suggesting the coordination of the carbonyl oxygen to the metal centre. Complex $\mathbf{1 b}$ showed broad intense bands at $1087,628 \mathrm{~cm}^{-1}$, assigned to the symmetric and asymmetric stretching of $v_{\mathrm{ClO} 4}^{-}$, respectively, and bands at 1669 and $3314 \mathrm{~cm}^{-1}$, assignable to the $v_{\mathrm{C}=\mathrm{N}}$ and $v_{\mathrm{N}-\mathrm{H}}$ stretching frequency, respectively. On the other hand, complex $\mathbf{2} \mathbf{b}$ showed a moderate band at $1383 \mathrm{~cm}^{-1}$ assigned to $\nu_{\mathrm{NO} 3}^{-}$. The bands at 3312,1472 $\mathrm{cm}^{-1}$ indicate the $v_{\mathrm{N}-\mathrm{H}}$ and $v_{\mathrm{C}=\mathrm{N}}$ stretching frequency, respectively.

\subsection{DNA binding studies}

The application of electronic absorption spectra in DNA binding studies is one of the most useful techniques. ${ }^{26}$ Generally, binding of the metal complex to the DNA helix is justified by an increase of the $n \rightarrow \pi^{*}$ band of 


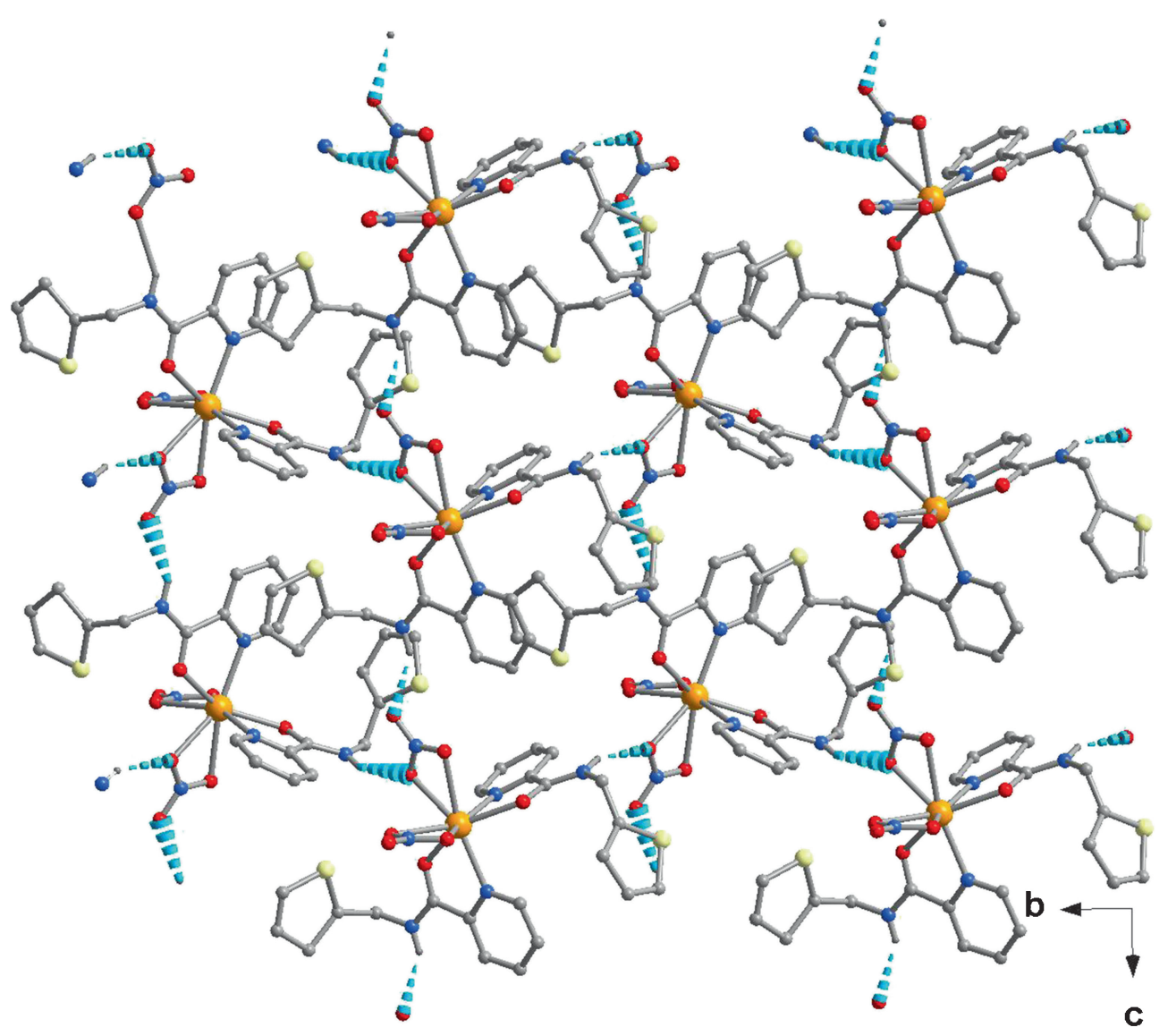

Figure 3. 2D hydrogen bonding network in the crystal packing of $\mathbf{2 b}$ (only $\mathrm{H}$ atoms of $\mathrm{NH}$ groups are indicated).

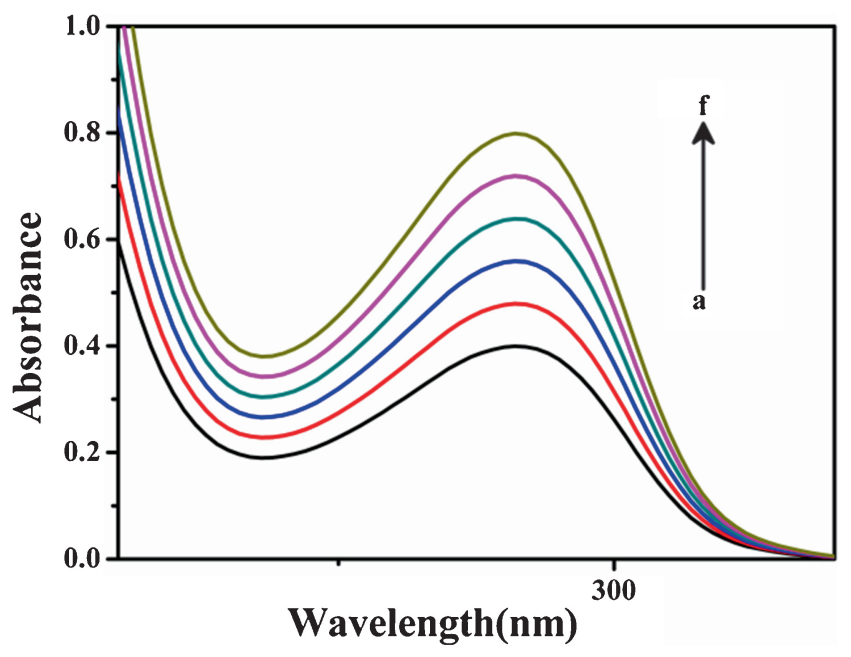

Figure 4. Electronic spectra of titration of complex 1a with CT-DNA (peak at $279 \mathrm{~nm}$ ) in tris- $\mathrm{HCl}$ buffer; [complex $]=2.47 \times 10^{-5} \mathrm{M}$; [DNA]: (a) 0.0 , (b) $1.01 \times 10^{-6}$, (c) $2.18 \times 10^{-6}$, (d) $3.364 \times 10^{6}$, (e) $4.669 \times 10^{-6}$ (f) $6.156 \times 10^{-6}$ (g) $7.32 \times 10^{-6} \mathrm{M}$. The arrow denotes the gradual increase of DNA concentration.

cadmium(II) complex due to the involvement of intercalative interactions between the effective chromophore of the complex and the base pairs of DNA. ${ }^{27-29}$ Here, the UV-Visible spectra of the cadmium(II) complexes in DMSO exhibited intense absorption bands at $c a$. $267 \mathrm{~nm}, 270 \mathrm{~nm}, 272 \mathrm{~nm}$ and $288 \mathrm{~nm}$ for the complexes 1a, 1b, 2a and $\mathbf{2 b}$, respectively, attributable to $\mathrm{n}-\pi^{*}$ transition (Table S1, in Supplementary Information). The absorption spectra of cadmium complexes in the absence and presence of CT-DNA (at a constant concentration of complex) are given in Figures 4, 5, S2 and S6 (Supplementary Information). The extent of the hyperchromism in the absorption band is generally consistent with the strength of intercalative interactions ${ }^{26,30-32}$ and these spectral characteristics suggest that the complexes interact with DNA, most likely through a stacking mode between an heterocyclic aromatic chromophore and the base pairs of DNA. ${ }^{33,34}$

In order to establish the binding strength of the metal complexes with CT-DNA, the association constant $\mathrm{K}_{\mathrm{b}}$ was determined from the spectral titration data using the Wolfe-Shimer equation (1): ${ }^{35}$

$[\mathrm{DNA}] /\left(\varepsilon_{\mathrm{a}}-\varepsilon_{\mathrm{f}}\right)=[\mathrm{DNA}] /\left(\varepsilon_{\mathrm{b}}-\varepsilon_{\mathrm{f}}\right)+1 /\left[\mathrm{K}_{\mathrm{b}}\left(\varepsilon_{\mathrm{b}}-\varepsilon_{\mathrm{f}}\right)\right]$

where [DNA] is the concentration of DNA, $\varepsilon_{\mathrm{f}}$ and $\varepsilon_{\mathrm{b}}$ correspond to the extinction coefficient, respectively, for the free complex and for the cadmium(II) complex 


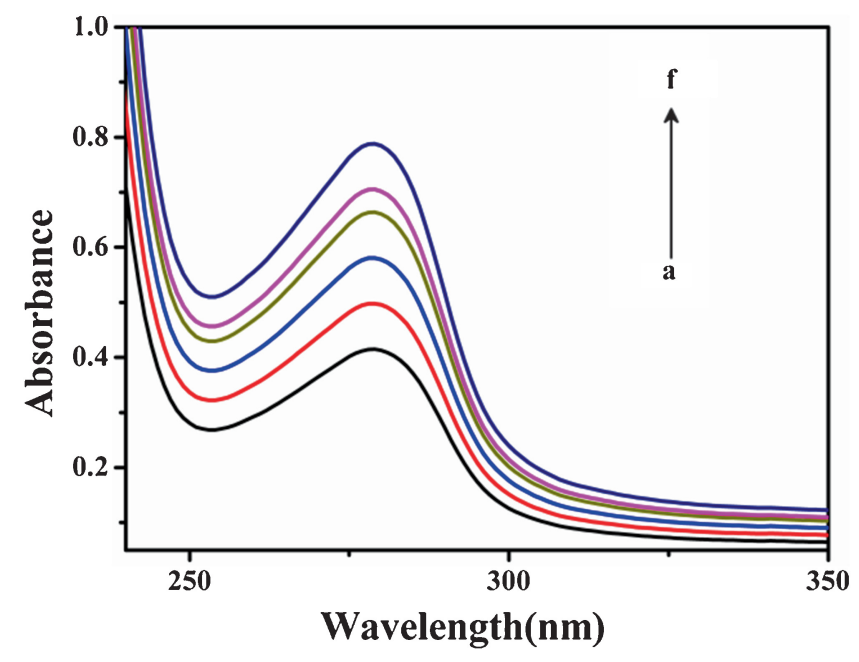

Figure 5. Electronic spectra titration of complex 2a with CT-DNA (peak at $279 \mathrm{~nm}$ ) in tris- $\mathrm{HCl}$ buffer; [complex] = $2.42 \times 10^{-5}$; [DNA]: (a) 0.0 , (b) $1.07 \times 10^{-6}$, (c) $2.28 \times 10^{-6}$, (d) $3.76 \times 10^{6}$, (e) $4.79 \times 10^{-6}$ (f) $6.56 \times 10^{-6} \mathrm{M}$. The arrow denotes the gradual increase of DNA concentration.

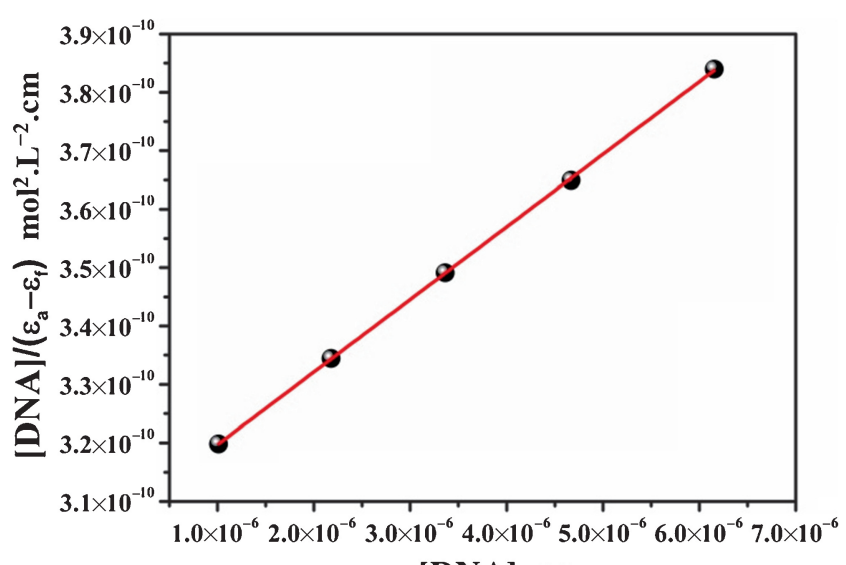

[DNA] (M)

Figure 6. Plot of [DNA] $/\left(\varepsilon_{\mathrm{a}}-\varepsilon_{\mathrm{f}}\right) v s$ [DNA] for the absorption titration of CT-DNA with the Cd(II) complex (1a) in tris-HCl buffer. $\mathrm{K}_{\mathrm{b}}=4.04 \times 10^{4} \mathrm{M}^{-1}$ for $(\mathrm{R}=0.999, \mathrm{n}=5$ points).

in the fully bound form, and $\varepsilon_{\mathrm{a}}$ is 'apparent' extinction coefficient for each addition of DNA to the cadmium(II) complex. Plots of [DNA] $/\left(\varepsilon_{\mathrm{a}}-\varepsilon_{\mathrm{f}}\right) v s$ [DNA] (Figures 6, 7, S3 and S7 in the Supplementary Information) gave the association constant $\mathrm{K}_{\mathrm{b}}$ as the ratio of slope to the intercept. The values of $\mathrm{K}_{\mathrm{b}}$ for the complexes were estimated to be: $4.04 \times 10^{4} \mathrm{M}^{-1}(\mathrm{R}=0.999, \mathrm{n}=5$ points $)$ for $1 \mathrm{a}, 8.18 \times 10^{4} \mathrm{M}^{-1}(\mathrm{R}=0.988, \mathrm{n}=5$ points $)$ for 2a, $4.9 \times 10^{4} \mathrm{M}^{-1}(\mathrm{R}=0.984, \mathrm{n}=4$ points $)$ for $\mathbf{1 b}$ and $1.11 \times 10^{5} \mathrm{M}^{-1}(\mathrm{R}=0.959, \mathrm{n}=5$ points $)$ for $2 \mathbf{b}$, indicating the following order $\mathbf{1 a}<\mathbf{1} \mathbf{b}<\mathbf{2} \mathbf{a}<\mathbf{2} \mathbf{b}$. These values are comparable to those previously reported for cadmium(II) complexes. ${ }^{36-39}$

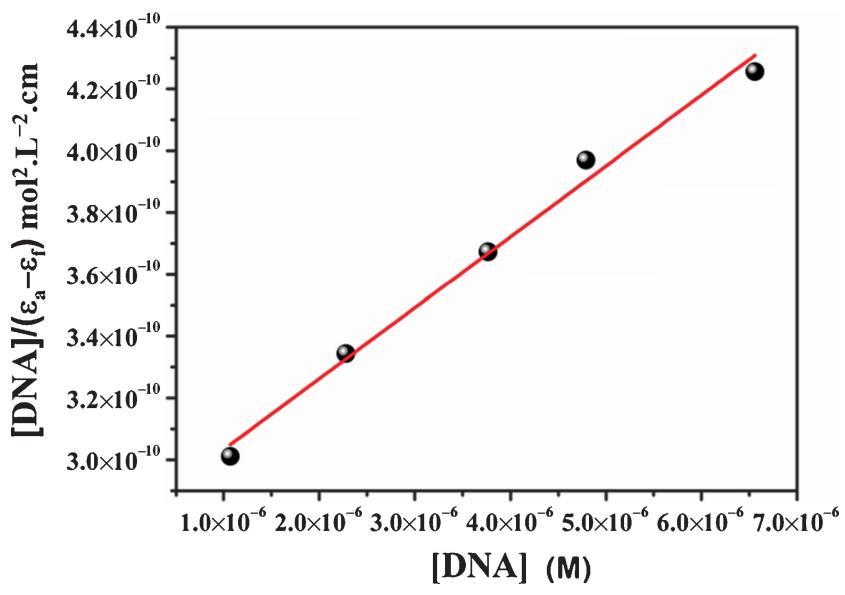

Figure 7. Plot of [DNA] $/\left(\varepsilon_{\mathrm{a}}-\varepsilon_{\mathrm{f}}\right) v s$ [DNA] for the absorption titration of CT-DNA with the Cd(II) complex (2a) in tris- $\mathrm{HCl}$ buffer. $\mathrm{K}_{\mathrm{b}}=8.18 \times 10^{4} \mathrm{M}^{-1}$ for $(\mathrm{R}=0.988, \mathrm{n}=5$ points).

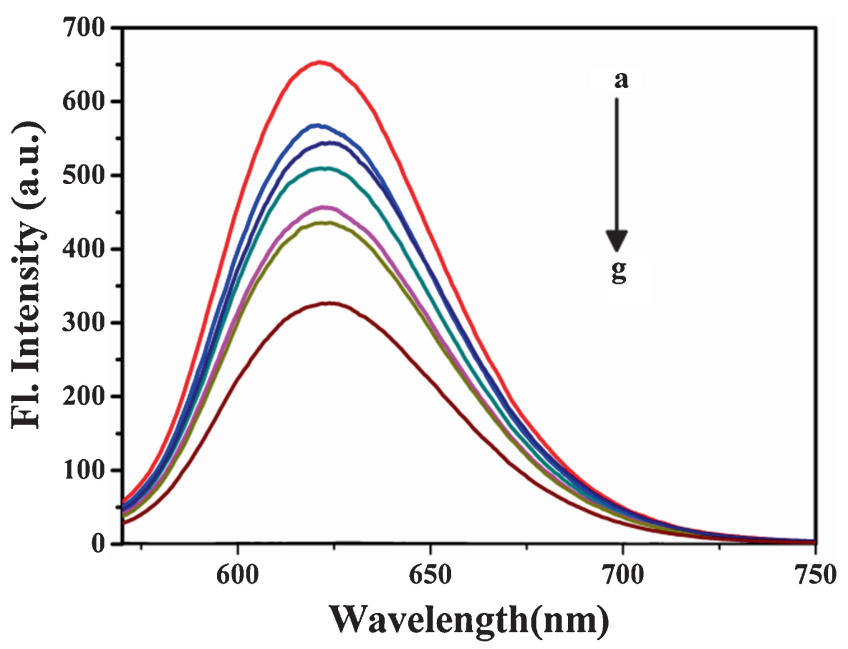

Figure 8. Emission spectra of the CT-DNA-EB system in tris- $\mathrm{HCl}$ buffer upon titration with complex 1a. $\lambda_{\text {ex }}=522$ $\mathrm{nm} ;[\mathrm{EB}]=1.03 \times 10^{-6} \mathrm{M},[\mathrm{DNA}]=1.23 \times 10^{-6} \mathrm{M}$; $[\mathrm{Com}-$ plex]: (a) 0.0 , (b) $3.02 \times 10^{-6}$, (c) $6.05 \times 10^{-6}$, (d) $9.07 \times 10^{-6}$, (e) $1.21 \times 10^{-5}$, (f) $1.51 \times 10^{-5}$, (g) $2.72 \times 10^{-5} \mathrm{M}$. The arrow denotes the gradual increase of complex concentration.

The binding of the complexes to DNA decreases the emission intensity and the extent of the reduction of the emission intensity gives a measure of the DNA binding propensity of the complexes and stacking interaction (intercalation) between the adjacent DNA base pairs. ${ }^{40}$ Although EB does not show any emission in the buffer medium due to fluorescence quenching by solvent molecules, it shows an emission band in the presence of CT-DNA due to intercalative binding to the helix. The decrease in fluorescence intensity of the DNA-bound EB (with excitation wavelength of 522 $\mathrm{nm}$ ) decreases with the increasing addition of the complexes (see Figures 8, 9, S4 and S8 in the Supplementary Information) because the binding of the complex 
to DNA promotes the release of the EB molecules from the double helix. ${ }^{41}$ This quenching due to the addition of the cadmium complex is in agreement with the Stern-Volmer equation (2): ${ }^{42}$

$$
\mathrm{I}_{0} / \mathrm{I}=1+\mathrm{K}_{\mathrm{sv}}[\mathrm{Q}]
$$

where $\mathrm{I}_{0}$ and $\mathrm{I}$ represent the fluorescence intensities in the absence and presence of quencher (complex), respectively, $\mathrm{K}_{\mathrm{sv}}$ is Stern-Volmer quenching constant, $\mathrm{Q}$ is the concentration of the quencher. In the quenching plot (see Figures 10, 11, S5 and S9 in the Supplementary Information) of $\mathrm{I}_{0} / \mathrm{I} v s$ [complex], $\mathrm{K}_{\mathrm{sv}}$ value is given by the slope of the regression line. The $\mathrm{K}_{\mathrm{sv}}$ values are $2.99 \times 10^{4}, 2.46 \times 10^{5}, 4.71 \times 10^{4}$ and 2.63 $\times 10^{5} \mathbf{M}^{-1}$ for complexes $\mathbf{1 a}, \mathbf{2 a}, \mathbf{1 b}$, and $\mathbf{2 b}$, respectively, suggesting a strong affinity of each cadmium(II) complex to CT-DNA. This feature may be attributed to a better ability of the complex to interact with DNA through intercalation binding, thus releasing EB from the EB-DNA complex. It is worth noting that the results obtained from the fluorescence spectra are in agreement with those derived from the absorption spectroscopy.

Furthermore, interactions between the complexes and DNA were investigated by viscosity measurement that is regarded as the most effective means to study intercalative binding mode of DNA in solution. ${ }^{43,44}$ The viscosity of DNA is sensitive to changes in DNA length upon interaction with a molecule and the solution viscosity $\left(\eta / \eta_{0}\right)$ and DNA length $\left(\mathrm{L} / \mathrm{L}_{0}\right)$ are related by the equation $\left(\mathrm{L} / \mathrm{L}_{0}\right)=\left(\eta / \eta_{0}\right)^{1 / 3} \cdot{ }^{46,47}$ A classical intercalative mode causes a significant increase of viscosity of

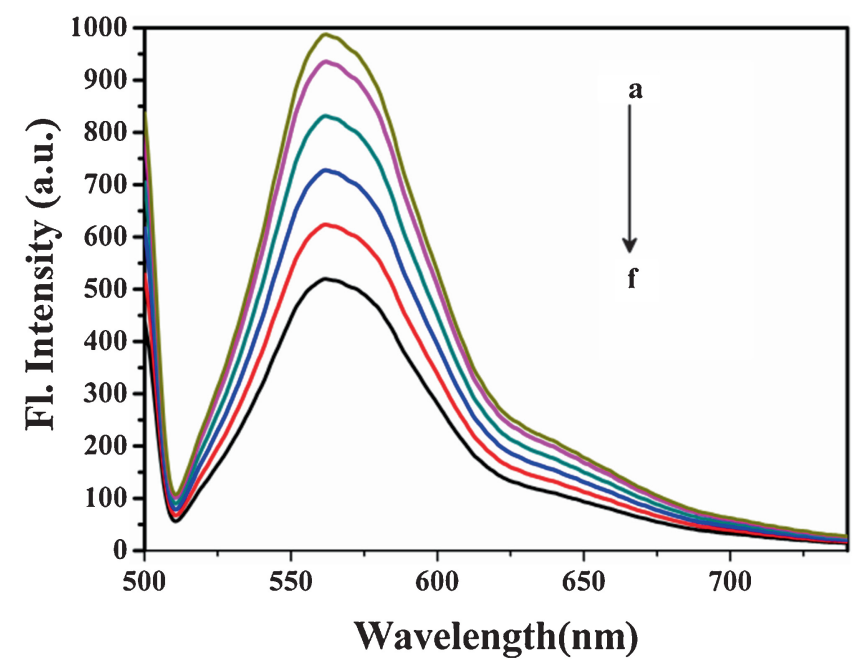

Figure 9. Emission spectra of the CT-DNA-EB system in tris- $\mathrm{HCl}$ buffer during the titration of complex $2 \mathbf{a}\left(\lambda_{\mathrm{ex}}=522\right.$ $\mathrm{nm})$. $[\mathrm{EB}]=1.03 \times 10^{-6} \mathrm{M}$, [DNA] $=1.23 \times 10^{-6} \mathrm{M}$; [Complex]: (a) 0.0 , (b) $1.07 \times 10^{-6}$, (c) $2.16 \times 10^{-6}$, (d) $3.04 \times 10^{-6}$, (e) $4.22 \times 10^{-6}$ and (f) $5.34 \times 10^{-6}$, M. The arrow shows increase in the complex concentration. the DNA solution due to a larger separation of intercalated base pairs leading to an increase of overall DNA length. In contrast, a molecule that binds exclusively in the DNA groove by partial and/or non-classical intercalation (i.e., electrostatic interaction or external groovebinding), a bend or kink in the DNA helix may be promoted leading to a slight shortening of its effective length. In this case, the change in viscosity of the DNA solution is less pronounced or there is no change at all. ${ }^{45-47}$ As indicated in Figure 12, the viscosity of complexes 2 increases with the increasing ratio of complex to CT-DNA. These results support the hypothesis that complexes $\underline{\mathbf{2}}$ bind to CT-DNA by intercalation, ${ }^{48,49}$ resembling the binding mode of EB to CT-DNA. In comparison to ethidium bromide, the relative viscosity is slightly lower for complexes $\underline{\mathbf{1}}$. The decrease in viscosity of DNA on addition of complexes $\mathbf{1 a}$ and $\mathbf{1 b}$ is

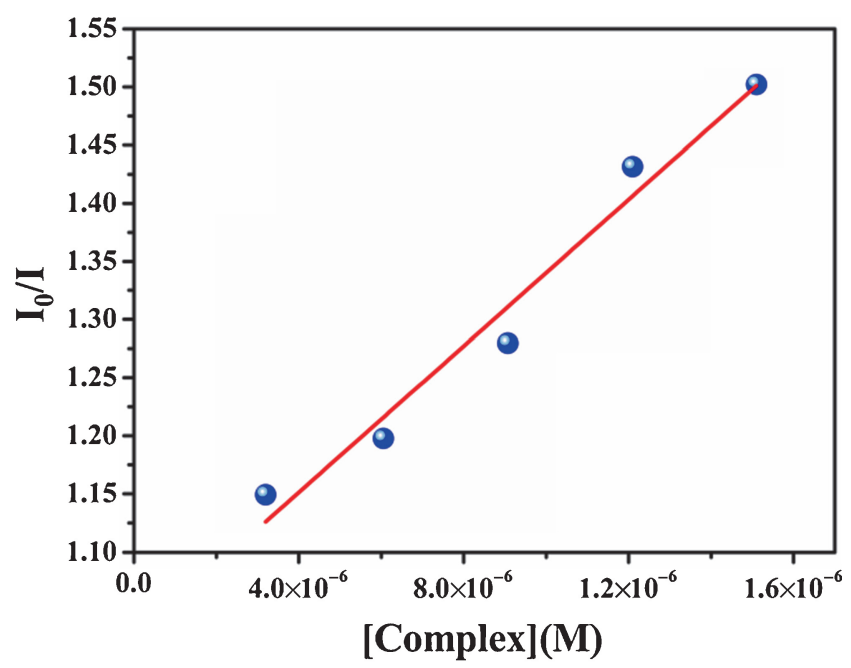

Figure 10. Plot of $\mathrm{I}_{0} / \mathrm{I} v s$. [complex 1a]; $\mathrm{K}_{\mathrm{sv}}=2.99 \times 10^{4}$ $\mathrm{M}(\mathrm{R}=0.964, \mathrm{n}=5$ points $)$.

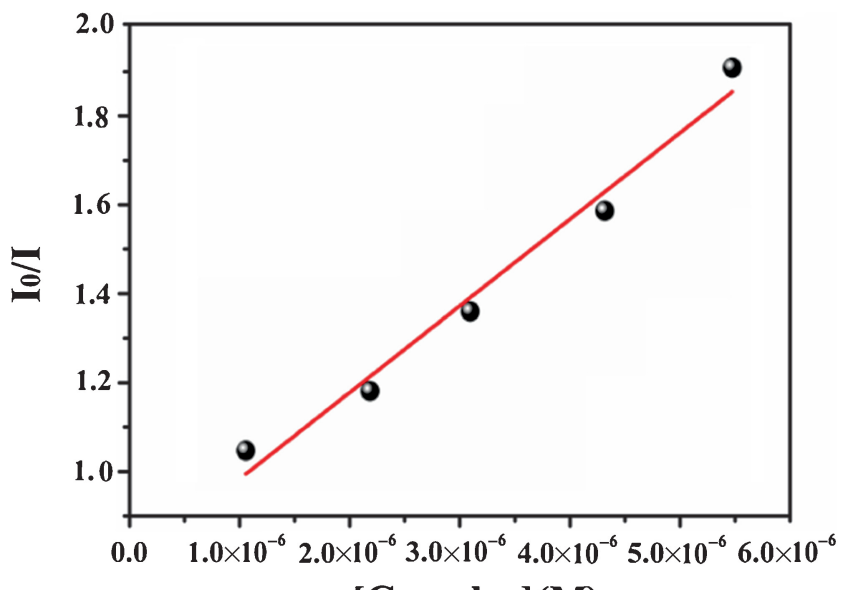

[Complex](M)

Figure 11. Plot of $\mathrm{I}_{0} / \mathrm{I} v s$. [complex 2a]; $\mathrm{K}_{\mathrm{sv}}=2.46 \times 10^{5}$ $\mathrm{M}(\mathrm{R}=0.973, \mathrm{n}=5$ points $)$. 


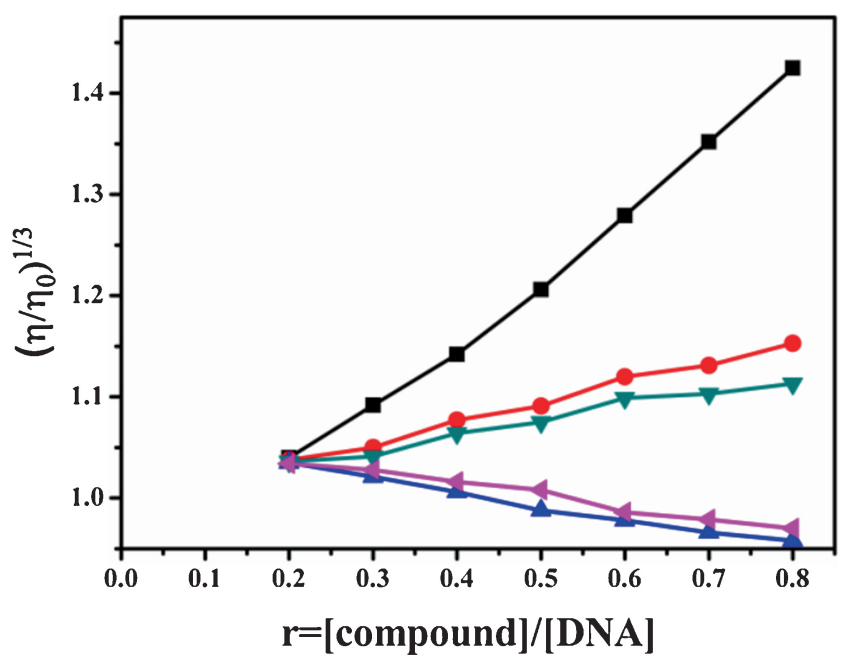

Figure 12. Change in the relative viscosity $\left(\eta / \eta_{\mathrm{o}}\right)^{\mathbf{1 / 3}}$ of CT-DNA as a function of $r$, the molar ratio of the complex to the DNA base pairs. The effect of increasing amount of the concentration of complex, $\mathbf{1 a}(\Delta), \mathbf{1 b}(\Delta), \mathbf{2} \mathbf{a}(\mathbf{}), \mathbf{2 b}(\nabla)$, and EB ( $\square)$ on the relative viscosity of CT-DNA.

indicative of electrostatic/covalent interaction..$^{50}$ It may be due to the presence of four non-planar ligand moieties in complexes (1), which probably play a key role to interact with DNA in electrostatic/covalent binding mode.

\section{Conclusions}

Carboxamide ligands ( $\mathbf{L}^{\mathbf{1}}$ and $\mathbf{L}^{\mathbf{2}}$ ) obtained in situ from pyridine-2-carboxylic acid with furfuryl amine and 2thiophenemethyl amine were reacted with perchlorate and nitrate salt of cadmium(II), separately, to afford four mononuclear cadmium complexes of formula $\left[\mathrm{Cd}(\underline{\mathbf{L}})_{4}\right]\left(\mathrm{ClO}_{4}\right)_{2}(\mathrm{~L}=\mathbf{1 a}$ and $\mathbf{1 b})$ and $\left[\mathrm{Cd}(\underline{\mathbf{L}})_{2}\left(\mathrm{ONO}_{2}\right)_{2}\right]$ $(\mathrm{L}=\mathbf{2 a}$ and $\mathbf{2 b})$. The $\mathrm{X}$-ray structural analysis indicated that the composition is anion dependent: in fact, perchlorate remained uncoordinated while the more coordinating nitrate anion is bound to cadmium(II) ion leading to cationic and neutral complexes, respectively. In this work, the detailed study is reported on the binding of complexes with CT-DNA, investigated by electronic absorption titrations, fluorescence spectroscopy, as well as by viscosity measurements, which indicated that complexes of different composition interfere differently with DNA. Actually weak electrostatic/covalent binding is detected with cationic complexes 1a and $\mathbf{1 b}$, while neutral complexes $\mathbf{2 a}$ and 2b bind to DNA via intercalation mode. However, the binding constants of these four eight coordinated cadmium(II) complexes are comparable to those of the previously reported six/five coordinated cadmium(II) complexes, ${ }^{36-39}$ but in some cases, the observed values are somewhat higher than those reported ${ }^{51-53}$ (Table S2 in Supplementary Information). The observed values listed in Table S2 clearly indicate that the five/six coordinated cadmium(II) complexes more strongly bound than the seven coordinated $\left(\mathrm{K}_{\mathrm{b}}=3.00 \times 10^{3} \mathrm{M}^{-1}\right)^{52}$ and eight-coordinated $\left(\mathrm{K}_{\mathrm{b}}=2.1 \times 10^{3} \mathrm{M}^{-1}\right)^{53}$ cadmium(II) complexes; i.e., with increase of coordinated group ligated with $\mathrm{Cd}(\mathrm{II})$ centre, decrease of binding constants $\left(\mathrm{K}_{\mathrm{b}}\right)$ was observed, but it is not valid in our case though the complexes are eight coordinated cadmium(II) complexes. Here, it is noteworthy to mention that both type of the complexes ( $\underline{\mathbf{1}}$ and $\underline{\mathbf{2}})$ are eight coordinated cadmium(II) complexes and they strongly interact with CT-DNA, comparable to the interaction of five and six coordinated cadmium(II) complexes.

\section{Supplementary Information (SI)}

Crystallographic data for the structural analyses of complexes 1a and 2b have been deposited with the Cambridge Crystallographic Data Centre bearing the CCDC Nos. 1438356 and 1438357, respectively. Copies of this information are available on request at free of charge from CCDC, Union Road, Cambridge, CB21EZ, UK (fax: +44-1223-336-033; e-mail: deposit@ccdc.ac.uk or http://www.ccdc.cam.ac.uk). NMR spectra (Figures S1-S4), plots of DNA binding experiments for complex $\mathbf{2 b}$ from the absorbance and emission study and its comparison with the complex $\mathbf{1}$ and other reported cadmium(II) complexes, and CIF files of complexes $\mathbf{1 a}$ and $\mathbf{2 b}$ are available at www.ias. ac.in/chemsci.

\section{Acknowledgements}

Financial support from the Council of Scientific and Industrial Research (CSIR), New Delhi, India [CSIR Scheme No. 01(2685)/12/EMR-II dated 03-10-2012] is gratefully acknowledged.

\section{References}

1. Lin J, Zhang J Y, Xu Y, Ke X K and Guo Z J 2001 N, $\mathrm{N}^{\prime}$-(1,2-phenylene)bis(pyridine-2-carboxamide) and $\mathrm{N}$, $\mathrm{N}^{\prime}$-(1,2-cyclohexanediyl)bis(pyridine-2-carboxamide) toluen hemisolvate Acta Crystallogr. Sect. C 57192

2. Trost B M and Hachiya I 1998 Asymmetric Molybdenum-Catalyzed Alkylations J. Am. Chem. Soc. 1201104

3. Epperson J D, Ming L J, Baker G R and Newkome G R 2001 Paramagnetic Cobalt(II) as an NMR Probe of Dendrimer Structure: Mobility and Cooperativity of Dendritic Arms J. Am. Chem. Soc. 1238583 
4. Collinson S R, Gelbrich T, Hursthouse M B and Tucker J H R 2001 Novel ferrocene receptors for barbiturates and ureas Chem. Commun. 555

5. Zhang J, Liu Q, Duan C, Shao Y, Ding J, Miao Z, You $X$ and Guo Z 2002 Structural evidence for the facile chelate-ring opening reactions of novel platinum(II)pyridine carboxamide complexes J. Chem. Soc., Dalton Trans. 22591

6. Li J, Zheng M L, King I, Doyle T W and Chan S H 2001 Syntheses and Antitumor Activities of Potent Inhibitors of Ribonucleotide Reductase 3-Amino-4Methylpyridine-2-Carboxaldehyde-Thiosemicarba-zone (3-Amp), 3-Amino-Pyridine-2-Carboxaldehyde-Thiosemicarbazone (3-Ap) and its Water-Soluble Prodrugs Curr. Med. Chem. 8121

7. He X M and Carter D C 1992 Atomic structure and chemistry of human serum albumin Nature 358209

8. Mukherjee T, Sen B, Zangrando E, Hundal G, Chattopadhyay B and Chattopadhyay P 2013 Palladium(II) and platinum(II) complexes of deprotonated $N, N$ /-bis(2-pyridinecarboxamide)-1,2-benzene: Synthesis, structural characterization and binding interactions with DNA and BSA Inorg. Chim. Acta 406176 and references therein

9. Singhal R N and Jain M 1997 Cadmium-Induced Changes in the Histology of Kidneys in Common Carp, Cyprinus carpio (Cyprinidae) Bull. Environ. Contam. Toxicol. $\mathbf{5 8} 456$

10. Hossain Z and Huq F 2002 Studies on the interaction between $\mathrm{Cd}^{2+}$ ions and nucleobases and nucleotides $J$. Inorg. Biochem. 9097

11. Hossain Z and Huq F 2002 Studies on the interaction between $\mathrm{Cd}^{2+}$ ions and DNA J. Inorg. Biochem. 9085

12. Genova P, Varadinova T, Matesanz A I, Marinova D and Souza P 2004 Toxic effects of bis(thiosemicarbazone) compounds and its palladium(II) complexes on herpes simplex virus growth Toxicol. Appl. Pharmacol. 197107

13. Hu W X, Zhou W, Xia C and Wen X 2006 Synthesis and anticancer activity of thiosemicarbazones Bioorg. Med. Chem. Lett. 162213

14. Filipović N R, Bacchi A, Lazić M, Pelizzi G, Radulović S, Sladić D M, Todorović T R and Anđelković K K 2008 Synthesis, structure and cytotoxic activity evaluation of a dinuclear complex of $\mathrm{Cd}(\mathrm{II})$ with $N^{\prime}, N^{\prime 2}$-bis[(1E)-1(2-pyridyl)ethylidene]propanedihydrazide Inorg. Chem. Commun. 1147

15. Bjelogrlic S, Todorovic T, Bacchi A, Zec M, Sladic D, Srdic-Rajic T, Radanovic D, Radulovic S, Pelizzi G and Andelkovic K 2010 Synthesis, structure and characterization of novel $\mathrm{Cd}(\mathrm{II})$ and $\mathrm{Zn}(\mathrm{II})$ complexes with the condensation product of 2-formylpyridine and selenosemicarbazide: Antiproliferative activity of the synthesized complexes and related selenosemicarbazone complexes J. Inorg. Biochem. 104673

16. Bertin G and Averbeck D 2006 Cadmium: Cellular effects, modifications of biomolecules, modulation of DNA repair and genotoxic consequences (a review) Biochimie 881549

17. Mondal B, Sen B, Zangrando E and Chattopadhyay $\mathrm{P}$ 2015 Zinc(II) complexes of carboxamide derivatives: Crystal structures and interaction with calf thymus DNA J. Chem. Sci. 1271747
18. Altomare A, Cascarano G, Giacovazzo C and Guagliardi A 1993 Completion and refinement of crystal structures with SIR92 J. Appl. Crystallogr. 26343

19. Sheldrick G M 2008 A short history of SHELX Acta Crystallogr. Sect. A: Found. Crystallogr. 64112

20. Farrugia L J 1999 WinGX suite for small-molecule single-crystal crystallography J. Appl. Crystallogr. 32 837

21. Marmur J 1961 A procedure for the isolation of deoxyribonucleic acid from micro-organisms J. Mol. Biol. 3 208

22. Reichmann M E, Rice S A, Thomas C A and Doty $\mathrm{P}$ 1954 A Further Examination of the Molecular Weight and Size of Desoxypentose Nucleic Acid J. Am. Chem. Soc. 763047

23. Barszcz B, Jablonska-Wawrzycka A, Stadnicka K and Hodorowicz S A 2005 The synthesis and structural characterization of novel zinc and cadmium complexes of chelating alcohol Inorg. Chem. Commun. 8951

24. Hakimi M, Moeini K, Mardani Z and Khorrami F 2012 Crystal Structure and Characterization of a New Eight Coordinated Cadmium Complex J. Kor. Chem. Soc. 57 352

25. Barszcz B, Hodorowicz S, Jablonska-Wawrzycka A and Stadnicka K 2005 Synthesis, X-ray structure and spectroscopic investigation of an eight-coordinate cadmium(II) complex J. Coord. Chem. $\mathbf{5 8} 203$

26. Barton J K, Danishefsky A and Goldberg J 1984 Tris(phenanthroline)ruthenium(II): Stereoselectivity in binding to DNA J. Am. Chem. Soc. 1062172

27. Sun J, Shuo W, An Y, Liu J, Gao F, Ji L N and Mao Z W 2008 Synthesis, crystal structure and DNA-binding properties of ruthenium(II) polypyridyl complexes with dicationic 2,2/-dipyridyl derivatives as ligands Polyhedron 272845

28. Lombardo V, Bonomi R, Sissi C and Mancin F 2010 Phosphate diesters and DNA hydrolysis by dinuclear $\mathrm{Zn}$ (II) complexes featuring a disulfide bridge and $\mathrm{H}-$ bond donors Tetrahedron $\mathbf{6 6} 2189$

29. Dhara K, Ratha J, Manassero M, Wang X Y, Gao S and Banerjee P 2007 Synthesis, crystal structure, magnetic property and oxidative DNA cleavage activity of an octanuclear copper(II) complex showing waterperchlorate helical network J. Inorg. Biochem. 10195

30. Dhara K, Roy P, Ratha J, Manassero M and Banerjee P 2007 Synthesis, crystal structure, magnetic property and DNA cleavage activity of a new terephthalate-bridged tetranuclear copper(II) complex Polyhedron 264509

31. Bloomfield V A, Crothers D M and Tinoco I 1974 In Physical Chemistry of Nucleic Acids (New York: Harper and Row) p. 432

32. Tysoe S A, Morgan R J, Baker A D and Strekas T C 1993 Spectroscopic investigation of differential binding modes of .DELTA.- and.LAMBDA.-Ru(bpy $)_{2}(\mathrm{ppz})^{2+}$ with calf thymus DNA J. Phys. Chem. 971707

33. Selvi P T, Stoeckli-Evans H and Palaniandavar M 2005 Synthesis, structure and DNA interaction of cobalt(III) bis-complexes of 1,3-bis(2-pyridylimino) isoindoline and 1,4,7-triazacyclononane J. Inorg. Biochem. 992110

34. Kelly J M, Tossi A B, McConnell D J and OhUigin C 1985 A study of the interactions of some polypyridylrutheniumn(I) complexes with DNA using fluorescence spectroscopy, topoisomerisation and thermal denaturation Nucl. Acids. Res. 136017 
35. Wolfe A, Shimer G and Meehan T 1987 Polycyclic aromatic hydrocarbons physically intercalate into duplex regions of denatured DNA Biochemistry 26 6392

36. Lu J, Sun Q, Li J L, Gu W, Tianab J L, Liuab X and Yan S P 2013 Synthesis, characterization, and DNA-binding of two new Cd(II) complexes with 8[(2-pyridylmethyl)amino]-quinoline J. Coord. Chem. 66 3280

37. Wu H L, Wang K T, Kou F, Jia F, Liu B, Yuan J K and Bai Y 2011 A six-coordinate picrate cadmium(II) complex with a new V-shaped ligand 1,3-bis(1ethylbenzimidazol-2-yl)-2-thiapropane: Synthesis, crystal structure, and DNA-binding properties J. Coord. Chem. 642676

38. Wu H L, Wang K, Jia F, Liu B, Kou F, Yuan J and Kong J 2010 Synthesis, characterization, and DNA band of a five-coordinate cadmium(II) complex with 1,3-bis(1-benzylbenzimidazol-2-yl)-2-thiapropane J. Coord. Chem. 634113

39. Wu H L, Yuan J, Huang X C, Kou F, Liu B, Jia F, Wang K T and Bai Y 2012 Two zinc(II) and cadmium(II) complexes based on the V-shaped ligand 2, 6-bis(2-benzimidazolyl)pyridine: Synthesis, crystal structure, DNA-binding properties and antioxidant activities Inorg. Chim. Acta 39012

40. Pyle A M, Rehmann J P, Meshoyrer R, Kumar C V, Turro N J and Barton J K 1989 Mixed-ligand complexes of ruthenium(II): Factors governing binding to DNA $J$. Am. Chem. Soc. 1113051

41. Vijayalakshmi R, Kanthimathi M, Subramanian V and Nair B U 2000 Interaction of DNA with $[\mathrm{Cr}$ (Schiff base) $\left(\mathrm{H}_{2} \mathrm{O}\right)_{2} \mathrm{ClO}_{4}$ Biochim. Biophys. Acta 1475 157

42. Stern O and Volmer M 1919 Über die Abklingzeit der Fluoreszenz Physik. Zeitschr. 20183

43. Kathiravan A and Renganathan R 2009 Photoinduced interactions between colloidal $\mathrm{TiO}_{2}$ nanoparticles and calf thymus-DNA Polyhedron 281374

44. Wang B, Yang Z Y, Crewdson P and Wang D 2007 Synthesis, crystal structure and DNA-binding studies of the $\mathrm{Ln}(\mathrm{III})$ complex with 6-hydroxychromone-3carbaldehyde benzoyl hydrazone J. Inorg. Biochem. 101 1492
45. Li D, Tian J, Gu W, Liu X and Yan S 2010 A novel 1,2,4triazole-based copper(II) complex: Synthesis, characterization, magnetic property and nuclease activity J. Inorg. Biochem. 104171

46. Garcia-Gimenez J L, Gonzalez-Alvarez M, LiuGonzalez M, Macias B, Borras J and Alzuet G 2009 Toward the development of metal-based synthetic nucleases: DNA binding and oxidative DNA cleavage of a mixed copper(II) complex with $N$-(9H-purin-6yl)benzenesulfonamide and 1,10-phenantroline. Antitumor activity in human Caco-2 cells and Jurkat $\mathrm{T}$ lymphocytes. Evaluation of p53 and Bcl-2 proteins in the apoptotic mechanism J. Inorg. Biochem. 103923

47. Tolia C, Papadopoulos A N, Raptopoulou C P, Psycharis V, Garino C, Salassa L and Psomas G 2013 Copper(II) interacting with the non-steroidal antiinflammatory drug flufenamic acid: Structure, antioxidant activity and binding to DNA and albumins J. Inorg. Biochem. 12353

48. Satyanarayana S, Daborusak J C and Chaires J B 1993 Tris(phenanthroline)ruthenium(II) enantiomer interactions with DNA: Mode and specificity of binding Biochemistry 322573

49. Satyanarayana S, Daborusak J C and Chaires J B 1992 Neither.DELTA.- nor.LAMBDA.-tris(phenanthroline) ruthenium(II) binds to DNA by classical intercalation Biochemistry 319319

50. Yuan C-X, Wu Y-B, Wei Y-B, Yang $\mathrm{P}$ and Zhu M L 2007 Studies on the Interaction of Dinitratobis(phen) Cadmium Complex with DNA Chin. J. Chem. 251267

51. Gao C, Ma X, Tian J, Li D and Yan S 2010 Synthesis, structure, and DNA binding of three reduced aminoacid Schiff-base zinc(II), nickel(II), and cadmium(II) complexes J. Coord. Chem. 63115

52. Ma X-F, Li D-D, Tian J-L, Kou Y-Y and Yan S-P 2009 DNA binding and cleavage activity of reduced aminoacid Schiff base complexes of cobalt(II), copper(II), and cadmium(II) Trans. Met. Chem. 34475

53. Park H, Kwon J H, Cho T, Kim J M, Hwang I H, Kim C, Kim S, Kim J and Kim S K 2013 Realtime detection of DNA cleavage induced by $\left[\mathrm{M}\left(2,2^{\prime}-\right.\right.$ bipyridine $\left.)_{2}\left(\mathrm{NO}_{3}\right)\right]\left(\mathrm{NO}_{3}\right) \quad(\mathrm{M}=\mathrm{Cu}(\mathrm{II}), \mathrm{Zn}(\mathrm{II})$ and $\mathrm{Cd}(\mathrm{II})$ ) complexes using linear dichroism technique $J$. Inorg. Biochem. 12746 